\title{
VOZES DA IGUALDADE: DISCURSOS SOBRE A PARTICIPAÇÃO DE MANUELA D'ÁvILA NO RODA VIVA
}

\section{Carlos Piovezani*}

(iD) https://orcid.org/0000-0002-3612-983X

Amanda Braga*

https://orcid.org/0000-0001-6026-5017

Como citar este artigo: PIOVEZANI, C.; BRAGA, A. Vozes da igualdade: discursos sobre a participação de Manuela D'Ávila no Roda Viva. Todas as Letras - Revista de Lingua e Literatura, São Paulo, v. 23, n. 2, p. 1-18, maio/ago. 2021. DOI 10.5935/19806914/eLETLL2 113278

Submissão: abril de 2020. Aceite: janeiro de 2021.

Resumo: Com base na Análise do Discurso, o artigo analisa uma série de textos e de enunciados que materializa distintas posições a propósito da postura dos entrevistadores do programa Roda Viva, da TV Cultura, exibido no dia 25 de junho de 2018, que teve como convidada a então pré-candidata à presidência da República Manuela D'Ávila. Os objetivos aqui consistem tanto em demonstrar que as discriminações da fala feminina se consolidaram de tal modo que continuam a se perpetuar em nossos dias quanto em indicar que, em oposição a essas discriminações de longa data, surgiram na sociedade brasileira de nossos dias posições igualitárias e feministas que lhes resistem, que as refutam e que se fazem ouvir.

Palavras-chave: Fala feminina. Manuela D’Ávila. Roda Viva. Discurso. Análise do Discurso. 


\section{INTRODUÇÃo}

Já há muito a fala feminina foi banida do campo da fala pública. Esse banimento tem uma força tamanha que seus ecos se estendem até os nossos dias, em que pesem as profundas transformações históricas que se processaram ao longo dos séculos. Por essa razão, uma história da fala pública (COURTINE; PIOVEZANI, 2015) não poderia contornar as exclusões e as discriminações de que a fala feminina foi continua e constantemente objeto.

Mais atuante do que talvez pudéssemos supor, há uma "sexuação" nas práticas e nas representações da fala pública. Essa sexuação consiste no fato de que as repartições entre as possibilidades e os efetivos exercícios da fala pública e entre seus poderes, alcances e efeitos são atravessadas e constituídas por uma histórica e social divisão entre os universos masculino e feminino. Ocorre, portanto, a formação de uma percepção sexuada da fala pública, cujo destino será longo e consistente. Em uma tal percepção,

[...] contrapõem-se a força viril do orador que fala e vence o tumulto dos auditórios e a passividade feminina sob a forma cômoda do silêncio; contrastam-se a virtude masculina da coragem exigida pela parrêsia e o vício feminino da bajulação e do eufemismo; demarcam-se, finalmente, o ideal masculino da voz, que se assentaria na harmonia firme e viril da fala e que remonta à força dos gritos de guerra e caça, e a feminidade sedutora do canto, no qual ecoariam a melodia de ninfas e sereias (COURTINE; PIOVEZANI, 2015, p. 17).

Partindo dessa contraposição entre o que seriam as forças e as aptidões masculinas para o desempenho oratório e o que se alega serem as fragilidades e as incompetências femininas para a fala pública, nosso artigo trata da longa duração histórica dos discursos conservadores que visam calar e/ou menosprezar a voz e a fala femininas. Com base na Análise do Discurso, o artigo analisa uma série de textos e de enunciados que materializam distintas posições a propósito da postura dos entrevistadores do programa Roda Viva, da TV Cultura, exibido no dia 25 de junho de 2018, que teve como convidada a então pré-candidata à presidência da República Manuela D’Ávila.

Os objetivos aqui consistem tanto em demonstrar que as discriminações da fala feminina se consolidaram de tal modo que continuam a se perpetuar em nossos dias quanto em indicar que, em oposição a essas discriminações de longa data, surgiram na sociedade brasileira de nossos dias posições igualitárias e feministas que lhes resistem, que as refutam e que se fazem ouvir.

$\mathrm{Na}$ esteira do que afirma Foucault (2001) sobre a ordem do discurso, nossa proposta se assenta na hipótese de que as relações sociais desniveladas, os mecanismos de reprodução social e os sistemas diversos de opressão e dominação produzem esta distribuição desigual: os discursos opressivos, que aberta ou dissimuladamente beneficiam poderosos e que direta ou indiretamente depreciam despossuídos, estão muito mais arraigados e são muito mais duradouros e difundidos do que os discursos igualitários e emancipatórios, conforme postulou Piovezani (2020). Esse funcionamento discursivo torna fundamentais uma análise e uma compreensão mais precisa dos discursos que detratam a fala feminina. 


\section{A voZ E A FALA FEMininas: BREVE GENEALOGIA DE UMA LONGA HiSTÓRIA DE DISCRIMINAÇÕES}

Na passagem da Odisseia, de Homero, que reproduzimos a seguir, materializa-se um discurso de silenciamento da fala pública feminina mediante um descrédito que lhe é impingido em sua comparação à fala pública masculina.

Cantava para eles o célebre aedo, e eles estavam sentados em silêncio a ouvir. Do triste regresso dos Aqueus cantava, do regresso que de Troia Palas Atena lhes infligira.

De seus altos aposentos ouviu o canto sortílego a filha de Icácio, a sensata Penélope.

E desceu da sua sala a escada elevada, não sozinha, pois duas criadas com ela seguiam.

Quando se aproximou dos pretendentes a mulher divina, ficou junto à coluna do teto bem construído, segurando à frente do rosto um véu brilhante.

De cada lado se colocara uma criada fiel.

Chorando assim falou ao aedo divino:

"Fémio, conheces muitos outros temas que encantam os homens, façanhas de homens e deuses, como as celebram os aedos. Uma delas cantam agora, enquanto estás aí sentado; e que eles em silêncio bebam o seu vinho. Mas cessa já esse canto tão triste, que sempre no meu peito o coração me despedaça, visto que em mim está entranhada uma dor inesquecível. Pois vem-me sempre à memória a saudade daquele rosto, do marido a quem toda a Hélade e Argos celebram." Tal resposta deu à mãe o prudente Telémaco:

"Minha mãe, por que razão levas a mal que o fiel aedo nos deleite de acordo com a sua inspiração? Não são culpados os aedos, mas Zeus: aos homens que por seu pão trabalham estabeleceu o destino que entendeu.

Não é justo levarmos a mal que ele cante a desgraça dos Dânaos. Pois os homens apreciam de preferência o canto que lhes pareça soar mais recente aos ouvidos. Que o teu espírito e o teu coração ousem ouvir. Não foi só Ulisses que perdeu o dia do retorno em Troia; também pereceram muitos outros.

Agora volta para os teus aposentos e presta atenção aos teus lavores, ao tear e à roca; e ordena às tuas servas que façam os seus trabalhos. Pois falar é aos homens que compete, a mim sobretudo: sou eu quem manda nesta casa." (HOMERO, 2010, p. 34-35, grifo nosso) ${ }^{1}$. 
Eis aí o momento em que Penélope desce de seus aposentos e dirige-se ao grande salão do palácio, onde seus pretendentes se amontoam à sua espera e à disposição de sua escolha. "Chorando", a frágil Penélope sugere ao aedo, que então cantava aos presentes, uma mudança na temática do que era entoado: o "canto tão triste" lhe trazia a memória de Ulisses, seu marido, de quem ainda esperava o retorno da Guerra de Troia. Telêmaco, por seu turno, interpelando a mãe, não apenas desautoriza a solicitação de Penélope, alegando que os aedos não tinham culpa do destino de Ulisses, como também lhe ordena o retorno aos trabalhos domésticos - aos "lavores, ao tear e à roca". Sua justificativa é a de que a fala pública é uma competência exclusivamente masculina: "falar é aos homens que compete". A postura de Telêmaco, que em nossos dias e a partir de uma posição progressista identificariamos como misógina, fora caracterizada por Homero como "prudente".

$\mathrm{Na}$ perspectiva homérica, a intervenção de Penélope é uma sequência de erros: ela erra em seu excessivo sentimentalismo ("Chorando assim falou ao aedo divino"; "cessa já esse canto tão triste,/ que sempre no meu peito o coração me despedaça"); erra ao se incomodar com o que canta o aedo e ao lhe sugerir que entoe tema distinto daquele que então cantava, pois, assim, parece desconhecer e desrespeitar "sua inspiração"; erra ao desconhecer que os aedos cantam o que cantam não movidos por sua própria vontade, mas por inspiração divina ("Não são culpados os aedos, mas Zeus"); erra pela ausência de empatia para com outros que se perderam no retorno de Troia, além de Ulisses ("Não foi só Ulisses que perdeu o dia do retorno/ em Troia; também pereceram muitos outros"); e erra por ter deixado seu espaço recluso e seus afazeres domésticos ("Agora volta para os teus aposentos e presta atenção/ aos teus lavores, ao tear e à roca"). Mas, sem dúvida, Penélope errou ainda mais por ter ousado falar em espaço quase público, por ali ter feito uma demanda e por não ter reconhecido a autoridade masculina de seu filho ("Pois falar é aos homens/ que compete, a mim sobretudo: sou eu quem manda nesta casa").

Se nos limitarmos ao universo ocidental, é possivel afirmar que esse é o "primeiro exemplo registrado de um homem mandando uma mulher 'calar a boca' e afirmando que a voz dela não deveria ser ouvida em público" (BEARD, 2018, p. 15). No entanto, a despeito dessa sua condição de primeiro registro escrito da opressão masculina sobre uma mulher, trata-se, numa perspectiva discursiva, de um enunciado que atesta o funcionamento de um anterior e já bem assentado dispositivo de silenciamento da fala pública feminina. Nele, a detratação desta última conjuga-se com o enaltecimento da competência da fala masculina. Já estabelecido, tal dispositivo daria, ainda, ensejo a uma longa história de discriminações.

Sua atuação não se restringiria, portanto, ao texto homérico. Ao longo da Antiguidade grega e latina, assistiremos a uma emergência contínua de suas operações, sob a forma de uma série de regularidades discursivas. Na passagem do período Arcaico ao período Clássico da Grécia Antiga, e com a entrada para um regime democrático de governo, outra obra, desta vez uma comédia, faria reverberar o silenciamento registrado na epopeia de Homero. Ekklesiazousai, que poderia ser traduzida por "as mulheres que se reúnem em assembleia" (POMPEU, 2016, p. 84), é a décima peça escrita por Aristófanes. Seu enredo consiste na reunião de um grupo de mulheres que, lideradas por Praxágora, vestem-se com trajes masculinos para ir à assembleia, espaço interditado à pre- 
sença feminina. Lá elas pretendiam discursar para o público e defender a entrega do Estado às mulheres. A comédia narra, então, os obstáculos encontrados pelo grupo para a realização desse projeto. Entre os empecilhos com que se depararam, estaria, não por acaso, a parca habilidade oratória, o que funciona, no texto, como parte de sua graça. Vejamos a seguir algumas passagens que materializam mais emblematicamente o menosprezo pela fala feminina:

[1 $1^{a}$ Mulher] E como uma associação de mulheres frágeis vai discursar na assembleia?

[Praxágora] De um modo excelente. Pois dizem dos jovens que, quanto mais enrabados, mais terríveis são no discursar. Assim, a coisa começa bem para nós.

[1 $1^{a}$ Mulher] Não sei, terrível é a falta de experiência.

[Praxágora] Mas não é esse o intuito de estarmos aqui reunidas: ensaiar o que devemos discursar lá? Você aí, não se antecipe em prender a barba; suponho que as outras já treinaram como falar.

[1 $1^{a}$ Mulher] E qual de nós já não é perita em falar, querida?

[...]

[Praxágora] Então vai, põe a coroa: vai dar tudo certo. Agora tente falar bonito como um homem, apoiando a postura na bengala.

[2 $2^{a}$ Mulher] Eu preferia que outro, desses acostumados a discursar, fizesse o melhor, enquanto eu assistiria calmamente sentada... (ARISTÓFANES in POMPEU, 2016, p. 85-86).

Pelos excertos, é possivel afirmar que o absurdo narrado pela comédia está assentado numa série de oposições: se, por um lado, o risivel reside no fato de que as mulheres, mesmo frágeis, querem discursar na assembleia ("E como uma associação de mulheres frágeis vai discursar na assembleia?”); por outro lado, como resíduo sintomático, tem-se a naturalização de um discurso segundo o qual a força é um pré-requisito para a fala. Uma vez que a força seria um atributo viril, a habilidade da fala torna-se apanágio masculino. Paráfrases possíveis do que se enuncia na comédia de Aristófanes seriam as seguintes: os homens são fortes e, por isso, podem discursar, e seu correlato, as mulheres são frágeis e, por isso, não podem discursar. Do mesmo modo, a exposição do que poderia ser uma alternativa que favoreceria as mulheres diante de sua suposta inaptidão concorre para os efeitos de humor da comédia: "dizem dos jovens que, quanto mais enrabados, mais terriveis são no discursar". Na busca por uma semelhança entre homens e mulheres que pudesse proporcionar uma boa desenvoltura oratória a estas últimas, ressalta-se o papel sexual passivo exercido por ambos, de que decorreria uma certa paridade retórica. A validade dessa equivalência é refutada logo em seguida, na medida em que se destaca a falta de experiência das mulheres nas práticas de fala pública, ainda que, hipoteticamente, fossem tão "enrabadas" quanto os bons oradores: "terrivel é a falta de experiência".

No mesmo sentido da depreciação da fala feminina, encontram-se os distin-

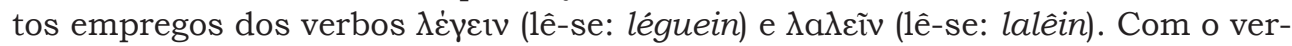
bo $\lambda \dot{\varepsilon} \gamma \varepsilon ı$, faz-se referência ao discurso a ser feito em assembleia e à sua necessidade de ensaio: "Mas não é esse o intuito de estarmos aqui reunidas: ensaiar 


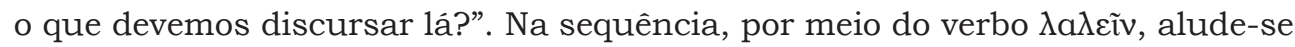
à fala das próprias mulheres ou à fala da qual já haviam se apropriado: "suponho que as outras já treinaram como falar. E qual de nós já não é perita em falar, querida?". De um lado, o grave discurso na assembleia; de outro, a frivola fala das mulheres. Ainda que os dois verbos remetam à mesma ação, não são os mesmos os sentidos produzidos por ambos.

Noutros termos, para o ato de discursar em assembleia, emprega-se $\lambda \dot{\varepsilon} \gamma \varepsilon ı$, cuja definição em dicionário seria, entre outras, "ler em voz alta; recitar; cantar; dizer; ordenar; dizer com insistência ou com autoridade; falar como orador" (MALHADAS; DEZOTTI; NEVES, 2006-2010)². Já a fala das mulheres, por sua

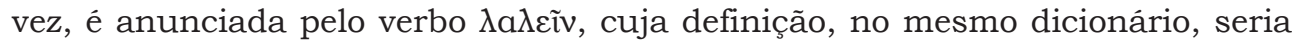
"emitir sons inarticulados; tagarelar; assunto objeto de falatório" (MALHADAS; DEZOTTI; NEVES, 2006-2010). É especificamente no exercício de fala proposto

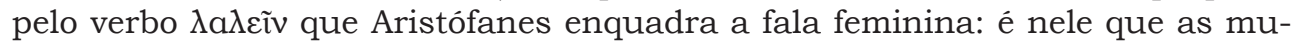
lheres são "peritas". Não por acaso, na sequência do excerto, Praxágora sugere a uma das mulheres que fale "bonito como um homem". A resposta de sua interlocutora expressa sua preferência e o que seria sua cômoda isenção: que um homem falasse em seu lugar, dado o seu costume em discursar. Nessa referência à fala masculina, novamente se utiliza o verbo $\lambda \dot{\varepsilon} \gamma \varepsilon \imath v$.

O deslocamento da Grécia para a Roma antiga e a passagem da filosofia para a poesia mitológica ensejam a observação e o registro de modificações sociais, mas não suficientes para a eliminação ou mesmo para uma significativa atenuação dos discursos que detratam a voz e a fala femininas. No início da Era Cristã, Roma assiste ao nascimento de Metamorfoses, de Ovídio. Uma de suas personagens femininas é Filomela. Seu infortúnio foi de ter sua língua cortada por Tereu, que a havia estuprado e que assim procedeu justamente para evitar sua denúncia pública:

Inclina Filomela o níveo colo,

Da espada, que vê nua, espera a morte;

Mas o duro, oferoz, por mais que a triste

Lute, resista, invoque o pátrio nome,

Com rígida torquês the aferra a língua,

A lingua, que falar em vão procura,

Lha extrai da boca, e rápido lha corta

A púrpura raiz the nada em sangue.

(OVÍDIO, 2016, p. 183) ${ }^{3}$.

Além da violência física e simbólica de que Filomela foi vítima, há nas Metamorfoses outros enunciados que materializam as práticas de interdição da fala feminina. Duas personagens têm sua capacidade vocal furtada. A primeira delas é Io. Tomada de ciúmes de seu marido Júpiter, Juno transforma Io em uma vaca, que perde, assim, o poder da fala articulada: "Súplices braços estender quisera/ Para o seu guardador, mas que é de braços? / Intenta dar um ai, solta um 
mugido:/ Treme do som, da sua voz se espanta" (OVÍDIO, 2016, p. 101)4. Já a segunda personagem feminina é a ninfa Eco. Considerada tagarela, Eco perde a autonomia de sua fala, passando apenas a repetir o final das frases que escuta: "Satúrnia entendeu/ e disse: 'a tua língua, que me iludiu tanto,/ pouco poder terá, no uso parvo da voz’./ E a ameaça confirma: quando alguém diz algo, Eco repete apenas o final das frases" (OVÍDIO apud CARVALHO, 2010, p. 101) ${ }^{5}$.

Além de conservar e estender discursos de detratação da voz e da fala feminina que já se materializaram em tantos textos da Antiguidade, os relatos mitológicos de Ovídio comportam, ainda, outro elemento de depreciação do campo feminino. Neles, não ocorrem somente o assalto da capacidade linguística e vocal das personagens, mas se destaca também a falta de sororidade. A solidariedade que poderia haver entre elas é ali substituída pela rivalidade, pelo ódio e pela vingança. Assim, o efeito que se produz é o de que as próprias mulheres seriam em boa medida as responsáveis pelo silenciamento que se abate sobre elas. Nesse caso, não é o universo masculino que sequestra a fala e a voz do feminino, mas, antes, as próprias deusas, heroínas e humanas é que o fariam umas às outras.

Se os discursos do preconceito contra a voz e a fala femininas materializam-se em textos ficcionais e filosóficos da Antiguidade, eles não deixaram de se materializar em enunciados do próprio campo que busca regular a fala pública (BRAGA; PIOVEZANI, 2021). Isso porque, em tratados de retórica, nos quais um dos objetivos consistia em estabelecer normas para corrigir o que eram considerados defeitos nos usos da voz e nos exercícios da fala, tais preconceitos voltam a ser reproduzidos. Ali, nas avaliações de suas diferenças, não há espaço nem possibilidade de mistura entre as vozes masculinas e femininas. Nesse domínio, a consagração e o descrédito são produzidos, ainda que não exclusivamente, por separações que se pretendem absolutas e definitivas. Observemos alguns exemplos desse funcionamento numa passagem da Instituição oratória, obra de Quintiliano, publicada por volta do ano de 95 de nossa Era:

Se desenvolvemos, em contrapartida, as qualidades da voz, tal como fazemos com todas as demais, mediante um cuidado atento, a negligência e a ignorância enfraquecem-nas. Mas esse cuidado não deve ser o mesmo para os oradores $e$ para mestres do canto; no entanto, há muitas condições comuns aos dois casos: a robustez da constituição corporal, para que nossa voz não seja fina e estridente, como a dos eunucos, das mulheres e dos doentes. Atingiremos esse resultado graças à marcha, às fricções, à continência e a uma digestão fácil, ou seja, à frugalidade. [...]

Porque aquele que está comprometido com inúmeras obrigações para com seus concidadãos precisa possuir uma voz robusta e resistente, ao invés de uma flexivel e delicada, uma vez que todos os cantores, modulando suas vozes, amolecem até mesmo os sons mais elevados, ao passo que nós, nós somos forçados em geral a adotar um tom áspero e veemente, a passar noites em vigília, a absorver a fumaça das velas e a prosseguir nosso trabalho com as vestes banhadas de suor (QUINTILIANO, Inst. orat. XI, 3, 19 e 23). 
A robustez e a resistência da voz podem ser compartilhadas por oradores e cantores, na medida em que permitem sua oposição à fineza e à estridência da voz dos eunucos, das mulheres e dos doentes. Contudo, a modulação, a flexão, o amolecimento e a delicadeza da voz masculina apenas pode frequentar a leveza e a recreação do entretenimento proporcionado pelos cantores, ao passo que na gravidade e na seriedade dos usos públicos dessa voz tais propriedades e inflexões vocais devem estar ausentes, em beneficio do "tom áspero e veemente".

Para Beard (2018), essa regularidade atestada nas práticas de silenciamento, de estigmatização da voz e da fala pública femininas seria quebrada no mundo antigo em apenas duas ocasiões: a primeira delas corresponderia às circunstâncias em que o acesso à fala pública se tornava possivel às mulheres para que elas se manifestassem na condição de vítimas ou de mártires. Ainda assim, em geral, tais manifestações não estavam investidas de significativa legitimidade. Já a segunda, por seu turno, refere-se a situações nas quais o assunto tratado permitia às mulheres a atuação como porta-vozes: por um lado, em algumas ocasiões, elas puderam falar em defesa de seus lares, de seus filhos e maridos; por outro, não thes era permitido falar pela comunidade, irrestritamente, ou mesmo pela classe masculina, mas apenas e tão somente em defesa dos interesses femininos. Excetuando-se esses relativamente raros episódios, há mais regularidades e continuidades de discursos segundo os quais as mulheres deveriam reservar sua voz à esfera e aos assuntos domésticos e femininos: "na maioria das circunstâncias, uma mulher que falasse em público não era, por definição, uma mulher" (BEARD, 2018, p. 29).

\section{Manuela D'Ávila no Roda VIva: TRÊs POSIções diversas}

Com vistas a melhor compreender os embates entre diferentes discursos sobre a fala feminina produzidos no Brasil contemporâneo, passamos a considerar a intersecção entre gênero e raça, mediante a análise de enunciados que materializam posições enunciativas distintas. Elas compartilham certos pressupostos, mas sua distinção está marcada pelo processo e pelo funcionamento discursivo de cada uma, nos quais as relações de equivalência e de encadeamento das coisas ditas são diferentes e, assim, constroem sentidos bastante diversos e até opostos entre si.

No dia 25 de junho de 2018, a pré-candidata à presidência da República Manuela D’Ávila foi a entrevistada do programa Roda Viva, da TV Cultura. Além de seu apresentador, Ricardo Lessa, participaram da entrevista Vera Magalhães, colunista do jornal O Estado de S. Paulo e comentarista da rádio Jovem Pan, Frederico D'Ávila, diretor da Sociedade Rural Brasileira, Letícia Casado, jornalista da Folha de S.Paulo em Brasília, João Gabriel de Lima, coordenador do curso de Jornalismo do Insper e colunista da revista Exame, e Joel Pinheiro da Fonseca, economista e colunista do jornal Folha de S.Paulo e da revista Exame. A bancada de entrevistadores era, portanto, constituída por duas mulheres e quatro homens. Ao desequilibrio entre os gêneros dos entrevistadores, soma-se a indistinção de suas posições ideológicas, uma vez que, grosso modo, todos não somente adeptos das práticas e ideologias neoliberais, mas também seus porta-vozes, que gozam de considerável visibilidade no cenário nacional e de boa dose de influência na formação da opinião pública brasileira. 
Nesse cenário, não seria surpreendente que a entrevistada tivesse de enfrentar questões delicadas e objeções às suas respostas. O que ocorreu, porém, naquela noite de junho, foi bem mais marcante do que isso. Considerando o fato de que o programa consiste no gênero entrevista, havia expectativa de que devesse prevalecer a fala da entrevistada ou, ao menos, a de que houvesse uma troca interlocutiva relativamente equilibrada, ainda que também mais ou menos hostil, sob a forma de um diálogo mais ou menos áspero. De fato, não foi somente isso o que aconteceu. A hostilidade e a aspereza não estiveram ausentes, mas o que mais se destacou naquela edição do Roda Viva foi a infindável série de interrupções sofridas pela pré-candidata à presidência. No decurso de suas respostas, Manuela D'Ávila foi interrompida em 62 ocasiões. Para muito facilmente constatar que esse não era um padrão do programa, muitas pessoas contrastaram o que se passara com a política do Partido Comunista do Brasil (PCdoB) e o que ocorrera durante a entrevista de Ciro Gomes, também concorrente ao mesmo posto nas eleições de 2018 pelo Partido Democrático Trabalhista (PDT). Ante as 62 interrupções da fala de Manuela, Ciro foi interrompido somente oito vezes.

Veículos da mídia de distintos segmentos e de diversos matizes ideológicos, bem como internautas e comunidades de várias redes sociais, manifestaram seu descontentamento e mesmo sua indignação ao que padecera a candidata. Dada toda a sua vasta extensão, reproduzimos a seguir somente alguns enunciados que materializaram essa posição contrária à dinâmica daquele Roda Viva:

Manuela D’Ávila vira alvo de manterrupting em entrevista no "Roda Viva" A pré-candidata à presidência Manuela D’Ávila foi interrompida mais de 60 vezes na entrevista que deu ao "Roda Viva”. Entenda o que é manterrupting.

Manuela D'Ávila, pré-candidata à presidência pelo $P C d o B$, esteve no programa "Roda Viva" dessa segunda-feira (25) e o que se viu foi um festival de manterrupting. Em inglês essa palavra é uma junção de man (homem) com interrupting (interrupção) e é usada para explicitar situações em que um ou mais homens fica $(m)$ interrompendo a fala de uma ou mais mulheres, impedindo que ela(s) conclua(m) o que estava sendo dito.

Num dos momentos em que isso ficou mais evidente, o entrevistador Frederico D’Ávila - que é assessor de Jair Bolsonaro - perguntou a Manuela se ela é a favor da castração química. Em resposta, a deputada começou a falar sobre cultura do estupro, dizendo que a solução para o problema está na educação. Frederico não deixou ela concluir o que dizia, introduzindo à conversa uma indagação sobre nazismo e Exército Vermelho - o que nada tinha a ver com a questão do estupro. Além disso, o homem também chegou a dizer que a cultura do estupro não existe (WARKEN, 2018).

Dilma, Ciro e Boulos criticam tratamento a Manuela D’Ávila no Roda Viva “Ataques machistas”, diz Dilma Rousseff (PT) sobre tratamento a Manuela D’Ávila, pré-candidata à Presidência pelo PCdoB interrompida 62 vezes pelos entrevistadores do programa Roda Viva, da TV Cultura

Ainda que concorrentes nas eleições presidenciais de 2018, o Partido dos Trabalhadores, Dilma Rousseff, Ciro Gomes e Guilherme Boulos repudiaram a postura dos entrevistadores do Roda Viva (TV Cultura) e manifestaram solidariedade 
à pré-candidata Manuela D'Ávila (PCdoB), que concedeu entrevista ao programa na noite de segunda-feira (25).

Para os mencionados, o tratamento a Manuela D'Ávila foi "machista" e visou "calar" a pré-candidata. A própria comunista divulgou, em sua página nas redes sociais da internet, uma comparação: Ciro Gomes (PDT), quando participou do programa, foi interrompido 8 vezes durante suas respostas aos entrevistadores; D’Ávila, por sua vez, foi interrompida 62 vezes.

Compunham a bancada, além de repórteres dos jornais Folha de $\mathrm{S}$. Paulo $e \mathrm{O}$ Estado de São Paulo, o coordenador da campanha de Jair Bolsonaro (PSL) Frederico D'Ávila. Os entrevistadores assumiram, em certos momentos, uma postura irônica contra Manuela que foge do tom usual do programa.

Partidos lamentam tratamento a Manuela D’Ávila

“Toda solidariedade à minha querida amiga Manuela D'Ávila, uma das lideranças politicas mais extraordinárias desse país. Podem até tentar, mas não vão conseguir calar essa voz", criticou o pré-candidato à Presidência Ciro Gomes (PDT).

Guilherme Boulos (PSOL), outro postulante ao Planalto, também se manifestou. "Roda viva expressou o machismo estrutural da sociedade brasileira. Solidariedade e unidade contra os retrocessos!", disse.

Já para a ex-presidente Dilma Rousseff (PT), "as grosserias contra Manuela no 'Roda Viva' são mais uma demonstração da parcialidade de uma imprensa que há muito abandonou qualquer resquício de isenção e imparcialidade, tornando-se uma facção política e partidária” (IG, 2018).

Internet indignada contra o programa Roda Viva aplaude coragem de Manuela D'Ávila

Veja aqui várias manifestações de internautas, jornalistas, políticos e personalidades contra o ataque sofrido por Manuela no Roda Viva

Foi uma tentativa de massacre. Jornalistas desinformados e preconceituosos e até mesmo um assessor de Bolsonaro avançaram contra a pré-candidata do $P C d o B$, Manuela D'Ávila, na noite desta segunda-feira (26), no programa Roda Viva, da TV Cultura. O sentimento machista e anticomunista era latente a cada pergunta, a cada interrupção.

Manuela, por sua vez, se manteve firme, respondeu a todos e não se alterou em momento algum diante das provocações. A internet, no entanto, amanheceu indignada com o antijornalismo praticado pela emissora e, sobretudo, com o tom das perguntas, provocações e interrupções dos entrevistadores.

O PCdoB chegou a fazer uma estatística com o número de interrupções que Manuela sofreu e comparou com as de Ciro Gomes, entrevistado em maio. A diferença foi acachapante. Manuela sofreu 62 interrupções contra apenas 8 de Ciro. Vários internautas, personalidades do jornalismo e da politica se manifestaram na manhã desta terça-feira (26). Veja algumas delas abaixo:

Benedita da Silva

@dasilvabenedita

Manuela D'Ávila deu um show no programa Roda Viva, apesar da alta dose de machismo e pegadinhas de jornalistas q ñ queriam entrevistar uma pré-candi- 
data p/ saber as suas ideias p/ o país, mas, sim, descontrui-lá. Não conseguiram, pois a MANU MANDOU MUITO BEM. @ManuelaDavila

Tarso Genro

Manuela se saiu muito bem enfrentando a ignorância, o preconceito e a falta de conhecimento da maioria dos seus adversários (não eram entrevistadores). Companheira orgulho da esquerda e grande candidata do campo democrático $e$ popular $^{6}$ (BITTENCOURT, 2018).

Conforme dissemos, há um manifesto posicionamento contrário às interrupções que Manuela D’Ávila sofreu em sua entrevista no Roda Viva em cada um desses três textos. O fato de se inscreverem no que parece ser uma mesma posição não torna idênticos os modos por meio dos quais esses canais formulam seus enunciados e materializam suas nuances discursivas. Uma vez que não pretendemos examiná-los minuciosamente, indicaremos apenas o que se apresenta como relevante diferença em seus temas e as formas como seus enunciadores concedem ou não espaço para a palavra de outrem. No texto do site Claudia, o foco recai no fenômeno da interrupção masculina da fala feminina, designado ali à inglesa, manterrupting, em sua definição trazida pela matéria:

Em inglês essa palavra é uma junção de man (homem) com interrupting (interrupção) e é usada para explicitar situações em que um ou mais homens fica $(m)$ interrompendo a fala de uma ou mais mulheres, impedindo que ela(s) conclua $(m)$ o que estava sendo dito.

E na menção a uma de suas ocorrências mais manifestas, a "interrupção mais evidente e hostil" de Frederico D'Ávila, coordenador da campanha de Jair Bolsonaro. Além disso, seu enunciador não se valeu de nenhuma forma de relatar o discurso de outrem que compartilhasse de sua própria posição.

Já no texto do portal $I G$, as críticas da ex-presidenta Dilma Rousseff e dos então candidatos Ciro Gomes e Guilherme Boulos ao tratamento dispensado à Manuela D'Ávila ocupam o primeiro plano. Ressalta-se, ainda, o fato de que, mesmo sendo "concorrentes", esses políticos e seus partidos manifestaram seu repúdio à "postura dos entrevistadores" do Roda Viva e sua "solidariedade" à candidata do PCdoB. A concessão de voz a outrem e a atribuição do que ali se diz a outro enunciador indicam que o texto mais menciona a posição contrária ao procedimento dos entrevistadores de Manuela do que propriamente assume e inscreve-se nessa posição. Isso não significa que esse posicionamento não seja adotado por seu enunciador, mas ele o faz de modo mais discreto e menos frequente do que se pode observar nos dois outros textos de que tratamos aqui. A única passagem em que se mostra a inscrição nessa posição é a seguinte:

6 Registre-se que na reportagem da revista Fórum, além das postagens de Benedita da Silva e de Tarso Genro, que reproduzimos aqui, há ainda mais 13 postagens de outras personalidades mais ou menos conhecidas dos campos político e midiático. 
Compunham a bancada, além de repórteres dos jornais Folha de $\mathrm{S}$. Paulo e $\mathrm{O}$ Estado de São Paulo, o coordenador da campanha de Jair Bolsonaro (PSL) Frederico D'Ávila. Os entrevistadores assumiram, em certos momentos, uma postura irônica contra Manuela que foge do tom usual do programa.

Nesse trecho, ainda assim, enfraquece-se a critica aos entrevistadores e ao Roda Viva, porque os primeiros somente "em certos momentos" manifestaram "uma postura irônica", e não agressiva, e porque tal procedimento "foge ao tom usual do programa".

Finalmente, o texto da revista Fórum tem um enunciador mais manifesta e solidamente comprometido com a posição progressista, a partir da qual critica o Roda Viva e os integrantes daquela sua edição. A seleção lexical é um índice seguro para observarmos a materialização desse posicionamento: o programa é descrito como "uma tentativa de massacre", os entrevistadores como "jornalistas desinformados e preconceituosos", que "avançaram" contra a candidata e a "provocaram", e a entrevistada como alguém que demonstrou "coragem", que "se manteve firme", que "respondeu a todos" e que "não se alterou em momento algum" diante de todos os ataques recebidos. Concorrem ainda para o fortalecimento dessa posição: 1. o recurso ao discurso direto, mediante o qual o enunciador reproduz "as manifestações de internautas, jornalistas, políticos e personalidades contra o ataque sofrido por Manuela no Roda Viva”, ou seja, o que ele próprio diz é subscrito por outros muitos e importantes sujeitos; 2. a generalização, a assimilação semântica e a personificação formuladas com o pré-construído "A internet amanheceu indignada"; e 3. o alegado gesto dêitico expresso na locução "Veja aqui", que produz o efeito de que o enunciador nada mais faz do que apontar a generalizada indignação com o que Manuela havia sofrido.

Os dias seguintes assistiram a um arrefecimento da repercussão daquele Roda Viva com Manuela D’Ávila, mas não a um seu esgotamento. No dia $1^{\circ}$ de julho, Djamila Ribeiro publicou o texto "Meus pitacos sobre o desrespeito sofrido por Manuela D'Ávila, no sofrivel programa Roda Viva” em seu perfil na rede social Facebook. Pesquisadora, ativista e uma das principais vozes do feminismo negro no Brasil, Djamila Ribeiro também assume nesse seu texto, tal como já observamos em seu título, uma posição contrária aos procedimentos de que se valeram os entrevistadores naquela edição do Roda Viva. Porém, diferentemente do posicionamento progressista predominante, que amparou Manuela, sua posição compreende também e mais fundamentalmente uma crítica a esta última. Reproduzimos a seguir quase a integra do texto de Ribeiro e procederemos, em seguida, à análise de alguns de seus aspectos:

Por terem sido construidos como os sujeitos do poder, homens brancos se julgam os grandes sabedores de tudo, mesmo que não saibam. Sujeitos que sempre foram autorizados a falar, entendem que em seus mundos só pode haver reciprocidade com sujeitos como eles, haja vista que muitos sequer enxergam humanidade nas mulheres ou em pessoas negras. [...] Em "Recusando-se a ser uma vitima", bell hooks discorre sobre o fato da identidade vitimada a qual muitas mulheres brancas preferem recorrer em vez de se prepararem para a resistência militante. A autora afirma que mulheres negras, historicamente, por saberem dos horrores do racismo e machismo, em vez de se esconderem na 
identidade vitimada, pensaram redes de solidariedade e de enfrentamento para não se fixarem num papel que lhes fora imposto. [...] O que precisamos fazer é encontrar formas de enfrentar, desestabilizar e não de nos esconder na fragilidade que eles impuseram às mulheres brancas. Porque aí se cai exatamente no papel que querem: daquelas que não sabem enfrentar uma situação difícil porque são "frágeis". É preciso romper com essa conveniência. Sabemos o quanto é duro ser mulher na politica, precisamos seguir lutando contra o machismo em todas as esferas, mas penso que não podemos mais nos dar ao luxo de ficarmos surpresas com situações como essa; é preciso entender a resistência militante como estratégia política de ação. Cair na identidade vitimada, quando Manuela tem todas as condições para fazer um debate, se posicionar, brigar para não ser interrompida, exigir que os entrevistadores a ouçam, ser agressiva, ainda mais quando se sabia estar num campo minado, é um caminho que julgo mais apropriado para além de se cair numa condescendência masculina que nos vê como alguém a ser protegida. [...] A nós, mulheres negras, como nos ensina as feministas negras, nunca nos coube esse papel. Somos as raivosas, agressivas, que fazem barraco. E por que? Porque em vez da identidade vitimada, escolhemos ir pra cima. E pagamos um preço alto por isso (RIBEIRO, 2018, grifo nosso).

Em consonância com a posição igualitária ora mais ora menos materializada nos textos publicados em Claudia, no portal IG e na revista Fórum, Djamila Ribeiro denuncia e ataca a injusta e desigual distribuição de oportunidades e de poderes da fala entre homens e mulheres, mas, desde o início de sua postagem, acrescenta à sua crítica a dimensão étnica: "Por terem sido construídos como os sujeitos do poder, homens brancos se julgam os grandes sabedores de tudo, mesmo que não saibam. Sujeitos que sempre foram autorizados a falar [....]". Seu posicionamento é reforçado pela enunciação em terceira pessoa, que lhe agrega o efeito de verdade à formulação. Na leitura do texto de Ribeiro, pode-se inferir que, segundo a autora, as interrupções sofridas por Manuela D'Ávila devem-se ao fato de que os homens brancos "entendem que em seus mundos só pode haver reciprocidade com sujeitos como eles, haja vista que muitos sequer enxergam humanidade nas mulheres ou em pessoas negras".

Para introduzir o que mais destoa da posição progressista dominante, Ribeiro recorre à voz autorizada de outrem. É a partir da referência a Gloria Jean Watkins, cujo pseudônimo é bell hooks (grafado com iniciais minúsculas), e de uma breve exposição da reflexão que essa autora faz num de seus textos, que Ribeiro passará à crítica ao modo como procedeu a candidata do PCdoB no Roda Viva. O argumento que Ribeiro traz de hooks é o de que mulheres brancas preferem recorrer à identidade vitimada a se "prepararem para a resistência militante". Ainda não é Djamila Ribeiro quem afirma o seguinte, mas a autora por ela citada:

[...] mulheres negras, historicamente, por saberem dos horrores do racismo $e$ machismo, em vez de se esconderem na identidade vitimada, pensaram redes de solidariedade e de enfrentamento para não se fixarem num papel que lhes fora imposto. 
Só depois desse preâmbulo é que identificamos o surgimento de uma outra relação entre a enunciadora e o que ela enuncia. Agora, o vínculo entre quem diz e a coisa dita se torna bem mais próximo e sólido. Esse vínculo se estabelece com os empregos da primeira pessoa do plural, ainda que seu uso e seus efeitos não sejam exatamente idênticos ao longo da sequência do texto. Nesta passagem, que introduz essa nova modalidade enunciativa, "O que precisamos fazer é encontrar formas de enfrentar, desestabilizar e não de nos esconder na fragilidade que eles impuseram às mulheres brancas.", há duas atualizações da primeira pessoa do plural, mas também duas ocorrências da terceira. Em "precisamos", temos um nós inclusivo ${ }^{7}$, que tanto pode compreender a enunciadora e as leitoras identificadas com a comunidade das mulheres feministas negras quanto ambas e ainda todos os sujeitos adeptos de sua causa. Já em "não de nos esconder na fragilidade", produz-se uma inclusão excludente da enunciadora e daquelas(es) que com ela já se identificam e que, por isso, já não se escondem na fragilidade. A própria postagem de Djamila Ribeiro e a imagem de si como alguém corajosa que ali se constrói pelo que ela diz e pelo modo como o faz concorrem para produzir essa desidentificação da enunciadora com esse "nos". Distintos ainda são os agentes designados por "eles" e por "mulheres brancas": os primeiros são aqueles que julgam saber e poder falar de tudo e as últimas são aquelas que se resignam com a identidade de vítimas e de frágeis.

Desse ponto até o final de seu texto, a primeira pessoa surgirá ainda 14 vezes. A totalidade dessas atualizações pode ser repartida em cinco subconjuntos, considerando os diferentes efeitos de sentido que se produzem em cada um deles. O primeiro é composto pela primeira pessoa do plural no seguinte caso: "Sabemos o quanto é duro ser mulher na política, precisamos seguir lutando", que é a reiteração do nós inclusivo, cuja abrangência tanto pode contemplar a enunciadora e as leitoras identificadas com a comunidade das mulheres feministas negras quanto ambas e ainda os partidários de sua causa. Um segundo pode compreender os dois usos da primeira pessoa do singular, "penso" e "julgo", com os quais a enunciadora pode postular algo, sem excessiva presunção, porque denotam uma ponderação subjetiva e uma mais particular expressão de uma posição. No terceiro, incluem-se estes dois verbos conjugados em primeira pessoa do plural e o pronome obliquo correspondente: "não podemos mais nos dar ao luxo de ficarmos surpresas". Há aqui a marcação do gênero feminino em "surpresas" que restringe a amplitude do nós inclusivo, tal como ocorre no primeiro conjunto. O próximo é constituído de um único pronome oblíquo de primeira pessoa do plural, que parece ser idêntico ao nós inclusivo anterior que se limita dada a marcação do feminino em "protegida". Porém, mediante as relações de equivalência que o discurso a que se filia a enunciadora estabelece entre as palavras, expressões e enunciados do texto, é possivel identificar que se trata, antes, daquela inclusão excludente da enunciadora e daquelas que com ela já se identificam, de que falamos no parágrafo precedente. O quinto e último conjunto compreende as seis últimas atualizações da primeira pessoa do plural:

7 Para mais informações sobre usos e efeitos do "nós", ver: Benveniste (1995), Indursky (1997), Zoppi-Fontana (1997) e Fiorin (2001). 
A nós, mulheres negras, como nos ensina as feministas negras, nunca nos coube esse papel. Somos as raivosas, agressivas, que fazem barraco. E por quê? Porque em vez da identidade vitimada, escolhemos ir pra cima. E pagamos um preço alto por isso.

Todas essas ocorrências estão subsumidas no escopo do sintagma "mulheres negras", uma vez que é ele o referente das formas remissivas a ele ligadas sob a forma da primeira pessoa do plural. Trata-se de um nós inclusivo, que apenas inclui a enunciadora e outras mulheres negras, como ela.

Anteriormente, haviamos feito referência à constituição de um ethos de coragem da enunciadora. Encerraremos a análise do texto de Djamila Ribeiro com o exame de alguns elementos que constroem essa imagem de si da enunciadora como corajosa. Algumas das acepções de coragem são assim definidas: "moral forte perante o perigo, os riscos"; "firmeza de espírito para enfrentar situação emocionalmente ou moralmente dificil"; "determinação no desempenho de uma atividade necessária” (HOUAISS; VILLAR, 2001, p. 834). É nessa direção que se orientam os sentidos da referência explícita à Manuela D'Ávila e da acusação de ter caído "na identidade vitimada" que lhe é dirigida, e ainda os sentidos das recomendações de procedimento político ("se posicionar, brigar para não ser interrompida, exigir que os entrevistadores a ouçam, ser agressiva") e da autoconstrução identitária ("Somos as raivosas, agressivas, que fazem barraco. E por quê? Porque em vez da identidade vitimada, escolhemos ir pra cima").

Em particular, esse último excerto do texto merece algumas considerações. A primeira delas é a de que se poderia afirmar que ele é mais uma declaração explícita da imagem da enunciadora sobre si mesma do que exatamente um componente de seu ethos. Isso porque o ethos constrói-se menos com base naquilo que diz o enunciador sobre si mesmo do que no assunto de que se propõe a tratar, do enfoque que lhe concede, da construção das personagens de seu texto, do registro de linguagem de que se vale, da corporeidade e da vocalidade enunciadas, entre outros componentes. Ainda assim, correlacionada com outras passagens do texto, esta última converge para a construção de um eu franco e corajoso, cujo corpo não somente está ereto, mas se ergue e permanece altivo, e cuja voz é firme, tensa e enérgica. Dito isso, é preciso acrescentar que se trata ali de uma reapropriação identitária, tal como ocorre com relativa frequência com grupos minoritários ou com maiorias marginalizadas, que se reaproveitam de estigmas que lhe haviam sido impostos, transformando-os em signos de luta e de resistência. Por essa razão, o enunciado "Somos as raivosas, agressivas, que fazem barraco" poderia ser assim parafraseado: Somos as que foram por tanto tempo e tantas vezes insultadas por homens brancos e por aqueles e aquelas que com eles se identificam como "as raivosas", "as agressivas", "as que fazem barraco", e que agora resolvemos nos reapropriar desses insultos que recebemos para lutar e resistir às opressões que nós, mulheres negras, sofremos e continuamos a sofrer.

Ainda que "raivosas", "agressivas", "que fazem barraco" e "escolhemos ir pra cima" carreguem essa memória das práticas e discursos que pretenderam e ainda pretendem calar a voz feminina, estigmatizar e deslegitimar sua fala, memória essa que tem uma longa duração histórica, quando esses termos e expressões são empregados, como no texto de Ribeiro, a partir de uma posição 
discursiva não só distinta, mas oposta à tradição misógina e patriarcal, passam a produzir sentidos bastante diferentes dos produzidos na posição que lhe é antagonista. Toda a disforia concentrada em cada traço semântico dessas palavras, locuções e orações e conservada por séculos numa memória antifeminina, que remonta ao menos até ao que disse Telêmaco à Penélope, é revertida na positividade da coragem de quem não foge aos perigos da luta. Em conjunto com a reapropriação identitária que nela se constituiu, a formulação "Somos as raivosas, agressivas, que fazem barraco" compreende ainda não uma essencialização e o estabelecimento de uma identidade fixa, mas, antes, sua recusa, porque "somos", no excerto, passa a significar "nos tornamos", "fomos obrigadas a nos tornar para poder resistir".

A possibilidade de que opositores, os não adeptos de suas lutas e de sua causa e os já progressistas, mas ainda não esclarecidos sobre as razões feministas, apontem nessa forma de batalha e resistência um excesso, parece-nos ser um sintoma de longa duração dos preconceitos e um ônus menor a ser pago nessa batalha ${ }^{8}$. Assim, talvez se minimize o disparate perverso que Jacques Rancière (1988, p. 11) observou se abater sobre o proletariado, qual seja, a "dupla e irremediável exclusão de viver como operários e falar como burgueses". Que as mulheres negras do Brasil contemporâneo não vivam como miseráveis nem precisem falar como madames.

\section{CONSIDERAÇÕES FINAIS}

Os exercícios de reflexão e análise que efetuamos aqui sobre discursos a propósito da fala feminina demonstram haver uma força tão sólida e um alcance tão extenso nesses discursos que eles atravessam várias e diversas fronteiras. Embora tenhamos assistido a uma longa série de profundas transformações históricas nas condições de produção dos dizeres e na diversidade dos tempos e dos lugares, dos campos de conhecimento e dos gêneros discursivos, as discriminações da fala feminina estabilizaram-se de tal forma que se conservaram até nossos dias. Foi isso que pudemos observar na postura dos entrevistadores do Roda Viva de que participou como convidada Manuela D'Ávila.

Contudo, conforme demonstramos, essa força e esse alcance não impediram que surgissem outras posições, desde aquelas que discordam dos posicionamentos conservadores, mas ainda ecoam alguns de seus preconceitos ou silenciam certas discriminações, tal como algumas daquelas que se posicionaram contra o procedimento dos entrevistadores do Roda Viva diante de Manuela D'Ávila, até aquelas mais aguerridas, tal como vimos no texto de Djamila Ribeiro. Diante de um vasto e consolidado conjunto de discursos que as depreciam e menosprezam, essas recentes vozes igualitárias e feministas confrontam e contestam esse conjunto de discursos, e, com muita luta, abrem espaços para serem cada vez mais ouvidas.

O exame que empreendemos aqui sobre enunciados do Brasil contemporâneo ilustra os poderes e perigos que se concentram na ordem do discurso. Uma

8 O projeto A representação social das professoras negras pelos discentes da UFBA, desenvolvido pelo Laboratório de Tecnologias Sócio-Raciais e de Metodologias de Redes da Universidade Federal da Bahia (Ufba), identificou a recorrência de dizeres como os seguintes a respeito das professoras negras: "Sua voz é alta demais, portanto agressiva, não tem sensibilidade no trato com outras pessoas, a louca, a desleixada, a desorganizada, muito objetiva, às vezes sua fala é tomada como preterição e então é a degenerada, a marcada, a descartável" (BRITO et al., 2018). 
dessas inquietações de que nos fala Foucault (2001, p. 8) é a da sua "existência transitória destinada a se apagar sem dúvida, mas segundo uma duração que não nos pertence". Se essa propriedade do discurso, assim, genericamente descrita, já nos perturba, deveríamos muito mais nos afligir com a consistência e a tenacidade dos discursos que reproduzem ora com maiores ora com menores modificações a percepção sexuada e discriminatória do campo da fala pública. Além disso, nossa análise indicou que as nuances ideológicas e discursivas devem ser indicadas o mais detalhadamente possivel, para que sejam devidamente observadas as diferenças no que pareceria ser uma mesma e única posição progressista e igualitária.

\section{Voices of Eguality: discourses about THE PARTicipation of MANuela D'Ávila IN RODA VIVA}

Abstract: Based on Discourse Analysis, the article analyzes a series of texts and statements that materialize different positions regarding the posture of the interviewers of the Roda Viva, of the TV Cultura, aired on June 25, 2018, which was invited as a pre-candidate for the presidency of the Republic, Manuela D'Ávila. The objectives here are both to demonstrate that the discriminations of female speech have consolidated in such a way that they continue to perpetuate today and to indicate that, in opposition to these long-standing discriminations, equal and feminist positions have emerged in Brazilian society of our days that resist them, refute them and that are heard.

Keywords: Female speech. Manuela D’Ávila. Roda Viva. Discourse. Discourse Analysis.

\section{REFERÊNCIAS}

BEARD, M. Mulheres e poder: um manifesto. Tradução Celina Portocarrero. São Paulo: Planeta do Brasil, 2018.

BENVENISTE, E. Estruturas das relações de pessoa no verbo. In: BENVENISTE, E. Problemas de linguistica geral I. Campinas: Editora da Unicamp: Pontes, 1995. p. 247-259.

BITTENCOURT, J. Internet indignada contra o programa Roda Viva aplaude coragem de Manuela D’Ávila. Fórum, 26 jun. 2018. Disponivel em: https://revistaforum.com.br/politica/internet-indignada-contra-o-programa-roda-viva-aplaude-coragem-de-manuela-davila/. Acesso em: $1^{\circ}$ abr. 2020.

BRAGA, A.; PIOVEZANI, C. Discursos sobre a fala feminina no Brasil contemporâneo. Revista da ABRALIN, v. 19, n. 1, p. 1-19, 2021.

BRITO, A. E. C. de. et al. A representação social das professoras negras pelos discentes da UFBA. Laboratório de Tecnologias Sócio-raciais e de Metodologia de Redes. Disponivel em: http://www.later.ufba.br/representacao.html. Acesso em: 5 nov. 2018.

CARVAlHO, R. N. B. de. Metamorfoses em tradução. 2010. 158 f. Relatório de pós-doutoramento (Pós-doutorado em Letras Clássicas) - Faculdade de Filosofia, Letras e Ciências Humanas, Universidade de São Paulo, São Paulo, 2010. 
COURTINE, J. J.; PIOVEZANI, C. (org.). História da fala pública: uma arqueologia dos poderes do discurso. Petrópolis: Vozes, 2015.

FIORIN, J. L. Categorias da enunciação e efeitos de sentido. In: BRAIT, B. (org.). Estudos enunciativos no Brasil: histórias e perspectivas. Campinas: Pontes, 2001. p. 107-129.

FOUCAUlT, M. A ordem do discurso. São Paulo: Loyola, 2001.

HOMERO. Odisseia. Tradução Frederico Lourenço. 8. ed. Lisboa: Livros Cotovia, 2010.

HOUAISS, A.; VILlAR, M. de S. Dicionário Houaiss da Língua Portuguesa. Rio de Janeiro: Objetiva, 2001.

IG. Dilma, Ciro e Boulos criticam tratamento a Manuela D'Ávila no Roda Viva. Ig, 26 jun. 2018. Disponivel em: https://ultimosegundo.ig.com.br/politica/ 2018-06-26/tratamento-a-manuela-davila-roda-viva.html. Acesso em: $1^{\circ}$ abr. 2020.

INDURSKY, F. A fala dos quartéis e outras vozes. Campinas: Editora da Unicamp, 1997.

MALHADAS, D.; DEZOTTI, M. C. C.; NEVES, M. H. M. Dicionário digital grego-português. 5 volumes. São Paulo: Atelier Editorial, 2006-2010. Disponivel em: http://perseidas.fclar.unesp.br. Acesso em: 29 out. 2019.

OVÍDIO. Metamorfoses. Tradução Manuel Bocage. Porto Alegre: Concreta, 2016. PIOVEZANI, C. A voz do povo: uma longa história de discriminações. Petrópolis: Vozes, 2020.

POMPEU, A. M. C. Tradução: excerto de Assembleia das mulheres, de Aristófanes. Transversal - Revista em Tradução, Fortaleza, v. 2, n. 1, p. 84-87, 2016.

QUINTILIANO. Institution oratoire. Paris: Les Belles Lettres, 2003.

RANCIĖRE, J. A noite dos proletários: arquivos do sonho operário. São Paulo: Companhia das Letras, 1988.

RIBEIRO, D. Meus pitacos sobre o desrespeito sofrido por Manuela D'Ávila, no sofrivel programa Roda Viva. Facebook, 27 jun. 2018. Disponivel em: https:// www.facebook.com/djamila.ribeiro.1/posts/2039258612774353. Acesso em: $1^{\circ}$ nov. 2019.

WARKEN, J. Manuela D'Ávila vira alvo de manterrupting em entrevista no 'Roda Viva'. Claudia, 26 jun. 2018. Disponivel em: https://claudia.abril.com.br/famosos / manuela-davila-vira-alvo-de-manterrupting-em-entrevista-no-roda-viva/. Acesso em: $1^{\circ}$ abr. 2020.

ZOPPI-FONTANA, M. Cidadãos modernos: discurso e representação política. Campinas: Editora da Unicamp, 1997. 